\title{
ASORTIMENTO FORMAVIMO PRINCIPAI MAŽMENINĖJE PREKYBOJE
}

\author{
Rasa Gudonavičienè \\ Kauno technologijos universitetas, Lietuva, rasa.gudonaviciene@ktu.lt \\ cross $^{\text {ref }}$ http://dx.doi.org/10.5755/j01.em.17.2.2193
}

\begin{abstract}
Assortment formation is a long and complex process, the stages of which are selected by each specific retailer depending of its priorities and needs. This article, in analysing the peculiarities of the assortment formation, suggests that the assortment policy helps to distinguish from competitors and attract more buyers. The works of Lithuanian scientists focus on the key aspects of the assortment policy - classification of the assortment, principles of formation. Foreign scientists elaborate on mathematical methods applicable in the assortment formation, problems of application of the methods.

The assortment formation of a retailer is related to the usage of some methods that would facilitate making of strategic decisions on assortment formation. However, no one opinion is prevailing so far which methods are the most suitable.

Objective of the paper is to develop a conceptual assortment formation model in retailing.

The result of research: in view of the summarised factors influencing assortment formation, a conceptual model of assortment formation in retailing is presented.

Keywords: retailing, assortment formation, factors influencing assortment formation, assortment forming process

JEL Classification: M31.
\end{abstract}

\section{Ivadas}

Asortimento formavimas yra ilgas ir sudètingas procesas, kurio etapus kiekviena mažmeninès prekybos įmonė pasirenka priklausomai nuo jos prioritetų ir poreikių. Deja, dažnai šis procesas praktikoje maksimaliai sutrumpinamas, siekiant greitų sprendimų, kurių efektyvumas ne visada pateisina imonès lūkesčius. Mokslininkai pastebi, kad asortimento valdymo, jo formavimo sprendimai gali būti maksimaliai pagrissti tik tuomet, kai šio proceso etapai yra igyvendinami nuosekliai, siekiant užsibrèžto tikslo, pasirenkant tinkamus metodus, atliekant tyrimus ir proceso kontrolę.

Lietuvos mokslininku darbuose (Sūdžius, 1997; Pajuodis, 2005; Pranulis, Pajuodis, Urbonavičius, Virvilaitè, 2011 ir kiti) didžiausias dèmesys skiriamas pagrindiniams asortimento politikos aspektams asortimento klasifikacijai, sąlygojantiems veiksniams, asortimento formavimo metodams

Užsienio šalių mokslininkai plačiau nagrinèja matematinius metodus, taikomus asortimento valdyme, tų metodų taikymo problematiką. Hsu, Bassok (1999) tiria ir analizuoja paklausos substituciją bei jos įtaką asortimento planavimui ir atsargu valdymo sprendimu prièmimui. Kiti autoriai asortimento formavimo sprendimus grindžia mažmeninès prekybos veiklos specifika (Dune, Lusch, 2005). Statinius (asortimentu grịstus) ir dinaminius (atsargomis grisstus) modelius plačiai analizuoja Mahajan ir van Ryzin (1999), Kök, Fisher, Vaidyanathan (2006), Parlar, Goyal (1984), Noonan (1995), Rajaram, Tang (2001) ir kiti autoriai.

Atlikta akademinès literatūros analizè leidžia pastebėti, kad dažnai tie patys procesai ívardijami skirtingais terminais: asortimento formavimas, asortimento planavimas ar jo valdymas. Lietuviškoje literatūroje dažniausiai vartojamas asortimento formavimo, o užsienio literatūroje - asortimento planavimo terminas. Taip pat vieni autoriai daugumą asortimento politikos aspektų analizuoja teorinëje plotmejje, o kiti linkę i lokalius tyrimus, kuriuose analizuoja vienų ar kitų asortimento formavimo matematiniu metodų taikymo privalumus bei trūkumus atskiroms prekèms, prekių kategorijoms. Pateikę pačius metodus, matematines jų išvestines, jie pritaiko juos konkrečioms prekiu grupėms konkrečiose geografinèse rinkose (Gürhan, Marshall, Ramnath, 2006), tuo pagrịsdami metodų privalumus bei teikiamų rezultatų pranašumus.

Apibendrinant galima pastebėti, kad mažmeninès prekybos imonès asortimento formavimas yra susijęs su tam tikrų metodų, kurie padètų priimti strateginius asortimento politikos sprendimus, panaudojimu. Tačiau iki šiol nèra vieningos nuomonès, kokie metodai tinkamiausi.

Straipsnio tikslas - parengti konceptualų mažmeninès prekybos asortimento formavimo modelị.

Straipsnyje naudoti šie tyrimo metodai: sisteminè ir palyginamoji mokslinès literatūros analizè.

Šio tyrimo rezultatas - apibendrinus asortimento klasifikavimo kriterijus ir sąlygojančius veiksnius, pateikiamas konceptualus asortimento formavimo mažmeninèje prekyboje modelis.

Mokslininkai, analizuojantys asortimento formavimą bei valdymą, pastebi, kad sprendimai gali būti maksimaliai pagrissti tik tuomet, kai asortimento planavimo, formavimo ir kontrolès darbai igyvendinami nuosekliai, siekiant užsibrèžto tikslo, pasirenkant tinkamus metodus, atliekant atitinkamus tyrimus ir analizę. 
Mažmeninės prekybos i̇monès asortimentas ne tik pritraukia pirkèją, bet ir padeda jam pasirinkti vieną ar kitą prekybos imonę iš kelių alternatyvių, padeda išsiskirti iš konkurentų.

Siais laikais mažos, nepriklausomos mažmeninès prekybos imonès retai kada matematiškai pagrindžia savo asortimento formavimą, kas dažnai sąlygoja neaktualių produktų užsakymus, neperkamų prekių kaupimą ir su tuo susijusias sąnaudas. Tenka pastebėti, kad XXI amžiuje dauguma mažmeninès prekybos tinklų tiek visame pasaulyje, tiek ir Lietuvoje asortimento formavimui, sprendimų, susijusių su jo optimizavimu, prièmimui naudoja specialiai sukurtas kompiuterines programas. Tačiau smulkios prekybos imonès ar nedideli tinklai asortimentą dar dažnai formuoja remdamiesi nuojauta ar aklai mègdžiodami konkurentus.

\section{Asortimento formavimą lemiantys veiksniai}

Asortimento formavimą, kaip ir bet koki kitą sprendimą įmonėje, lemia daugybė ịvairių veiksnių, kuriuos būtina numatyti ir įvertinti siekiant geriausių rezultatų. Analizuojant mokslinę literatūrą, pastebima, kad tiek Lietuvos, tiek ir užsienio autoriai skiria labai skirtingus veiksnius, kurie, jų nuomone, lemia asortimento formavimą mažmeninèje įmonèje. Šiame poskyryje bus siekiama nustatyti, kokie tai veiksniai ir kaip jie lemia atitinkamos i̇monès asortimento formavimą.

Mokslininkai pastebi, kad asortimento formavimas pirmiausia turi būti pagristas pirkëjų srautų ir ju elgsenos charakteristikomis (Fox, Sethuraman, 2006; Mantrala, Levy, Kahn, Fox, Gaidarev, Dankworth, Shah, 2009; Grewal, Levy, Mehrotra, Sharma, 1999; Levy, Weitz, 2008) Šie autoriai pastebi, kad mažmenininkai lokalizuoja asortimentą taip, kad geriau patenkintų savo pirkèjų poreikius.

Misra (2008) teigia, kad, formuodama asortimentą, mažmeninès prekybos imonè turi prisitaikyti prie nuolat kintančių rinkos sąlygų, kurias apibūdina pokyčiai pasiūloje (atsiranda naujų prekių, naujų tiekèjų, keičiasi kainos), pokyčiai paklausoje (kinta pajamos, mada, skonis, aptarnaujamas rajonas), pokyčiai konkurentu veiksmuose (keičiasi konkurentu veiksmai, atsiranda nauju konkurentu), pokyčiai makro aplinkoje. Galima teigti, kad autorius, išskirdamas asortimento valdymui įtaką darančius veiksnius labiau orientuojasi į išorinę imonès aplinką, šalies ekonominę bei teisinę situaciją.

Panašius veiksnius išskiria ir Simonson (1999). Tik autorius nedetalizuoja veiksnių ir per daug neaiškina, kokie elementai sudaro atitinkamu veiksniu grupę. Jis tik pažymi, kad įmonès asortimento formavimą lemia 4 veiksnių grupės: išorès, vidaus, rinkos, asortimento ryšio (sąsaju). Tokios pat nuomonès prisilaiko ir Pajuodis (2005). Remiantis šiais autoriai, galima teigti, kad įmonès asortimento politikai itaką daro visa imonès aplinka - tiek išorinè, tiek ir vidinè (Linehan, Cadogan, 2003; Pranulis, Pajuodis, Urbonavičius, Virvilaitè, 2011; Dune, Lusch, 2005). Simonson (1999) nedetalizuoja asortimento veiksniu grupès, tačiau galima būtų daryti prielaida, kad išskirdamas ši veiksni, autorius kalba apie prekes, jų linijas bei kategorijas.

Kalbant apie išorinius veiksnius, Chernev (2006) nurodo, jog esminis veiksnys formuojant ar tobulinant prekių asortimenta, priimant sprendimus dèl asortimento prekių kainodaros yra vartotoju poreikiai. Imonè, vystydama asortimenta, privalo įvertinti: vartotojų poreikius, vartotojų suvokiamą naudą iš ¿̨monės prekių, kiek pirkejjui pinigų, laiko, pastangų kainuoja surasti įmonès prekes, išsirinkti reikiamą prekę.

Kotler, Amstrong, Saunders, Wong (2003) daugiau pažymi artimesnę i̇monei aplinką ir pagrindini dèmesị skiria jo vidaus politikai. Šie autoriai teigia, kad įmonès asortimento pokyčiu lemia šie veiksniai:

- prekybos šaka, kurioje veikia įmonè,

- jos dydis,

- buvimo vieta,

- darbuotojų kvalifikacija,

- disponuojamas kapitalas ir kt.

Galima teigti, kad Gaur, Honhon (2006) detalizuoja Simonson (1999) išskirtą asortimento veiksni. Šie autoriai teigia, kad valdant ịmonès asortimentą turi būti ịvertinta:

- prekiu įvairové ir prekių linijos;

- multi prekinè problema (ši problema atsiranda tuomet, kai ant tos pačios lentynos parduodamos įvairių gamintojų prekès-substitutai);

- lentynų pajègumas;

- paklausa bei jos pokyčiai;

- pirkèjo (dažniausiai ir vartotojo) sprendimo prièmimo procesas; 
- egzogeninè paklausa, kuri vertinama ne produktų grupei, bet kiekvienam produkto vienetui atskirai;

- vietos pasirinkimas.

Išsamiausia yra pastaroji veiksnių klasifikacija, kuri praktiškai apima visus pagrindinius asortimento politikos sprendimus. Žinoma, išorinè aplinka, tokia kaip ekonominè, teisinè-politinè, labai svarbios, tačiau tiesioginès itakos asortimento valdymui neturi. Be to, ekonominès aplinkos, socialinès aplinkos itaka vertinama per pirkëjo sprendimo prièmimo procesą, todèl vertinti du skirtingai išskiriamus veiksnius du kartus per tą pačią prizmę, nèra tikslinga.

Formuodama konkretų asortimentą imonė turi prisitaikyti prie nuolat kintančių rinkos sąlygų, prie pasikeitimu pasiūloje, paklausoje, konkurencineje aplinkoje. Asortimento pasikeitimai gali vykti ir dẻl kitu veiksniu, pvz. dèl imonès savininko ar vadovo pasikeitimo, pasikeitus prekybos formai ir kt.

Formuojant prekių asortimentą būtina atsižvelgti i paklausos kompleksiškumą, i tai, kad tarp prekiu yra tam tikras ryšys, kad kai kurių prekių vartojimas yra susijęs. Itakos asortimento formavimui taip pat gali turèti impulsyvaus pirkimo augimo tendencijos tam tikrose prekių grupèse bei tiesioginių konkurentu asortimento politika. Pirkèjų srautai taip pat turi nemažą reikšmę prekių asortimentui. Todèl dažna mažmeninès prekybos i̇monė skaičiuoja, kiek pirkejjų apsilankè parduotuvejje per dieną, kaip jie pasiskirstė pagal valandas, kiek ir kokių prekių jie issigijo ir kokia dalis pirkèjų išèjo iš parduotuvès be pirkinio. Tobulinant prekių asortimentą labai svarbu atsižvelgti i sezoninius paklausos ir pasiūlos svyravimus, madą.

Apibendrinant galima daryti išvadą, kad asortimentui darančiu itaką veiksnių struktūra priklauso nuo imonès veiklos, tikslų, prioritetu rinkoje, tačiau kaip pagrindinius veiksnius galima ịvardinti pirkejju poreikius bei konkurentų asortimento politiką.

\section{Asortimento klasifikavimo kriterijai}

Prekę galima apibrèžti kaip darbo ir pastangu apčiuopiamą arba neapčiuopiamą rezultatą, kaip kažką, ką galima pasiūlyti rinkai, patenkinant jos norus ir poreikius (Kotler, Keller, 2007) arba kaip mainams pagamintą produktą.

Prekybos įmonėse parduodama daugybė ịvairiausių prekių. Atsižvelgiant i keliamus tikslus, jos ivairiai skirstomos, klasifikuojamos. Assel (1974) pažymi, kad prekiu klasifikacija yra schema, kurios pagalba apibendrinamos prekiu savybės bei rinkos atsakas i tas prekes. Prekybos įmonių marketinge prekiu klasifikavimo tikslas - sudaryti galimybę efektyviau valdyti asortimenta, priimti racionalius asortimento politikos sprendimus. İvairios prekių klasifikacijos skiriasi klasifikavimo požymiais ir praktine nauda (Pajuodis, 2005).

Marketingo mokslui yra žinoma keletas prekių skirstymo i̇ grupes požymių, kurie padeda vadovams bei specialistams rengti ir igyvendinti marketingo planus.

Kaip pažymi Hyman, Sharma, Krishnamurthy (1994), pirmają prekių klasifikaciją pasiūlè Parlin 1912 m. Pagal šią klasifikaciją prekės skirstomos i 2 grupes - kasdieninio vartojimo bei specialiai pasirenkamas. Skalen, Fougere, Felleson (2008) nurodo, kad Copeland (1923) klasifikacijoje prekès skirstomos i 3 grupes, t.y. prie Parlin išskirtu grupių dar pridedama viena - ypatingosios prekès, o Rhoades (1927) savo pasiūlytą klasifikaciją grindè trimis veiksniais - prekès naudojimo charakteristikomis, fizinèmis prekèmis charakteristikomis, prekès gamybos charakteristikomis.

Šiuolaikiniai autoriai (Kotler, Keller, 2007; Pajuodis, 2005; Pranulis, Pajuodis, Urbonavičius, Virvilaite, 2011; Sūdžius, 1997 ir kt.) vartojamąsias prekes klasifikuoja kur kas detaliau. Toks klasifikavimas yra pagrịstas prekiu apčiuopiamumu, pirkimo elgsena, vartojimo ipročiais. Šie autoriai išskiria: kasdienes paklausos prekes, pasirenkamos paklausos prekes, ypatingos paklausos prekes, pasyvios paklausos prekes, nepageidautinos paklausos prekes. Tačiau ir toks skirstymas nèra pakankamas asortimento valdymui.

Dune, Lusch (2005), Pranulis, Pajuodis, Urbonavičius, Virvilaitė (2011), Sullivan ir Adcock (2002) pateikia daugybę požymių pagal kuriuos galima klasifikuoti prekių asortimentą: vietos, laiko kriterijai, prekiu pasiūlos principai, prekiu paskirtis, vartojimo būdas.

Kiti autoriai asortimentą klasifikuoja priklausomai nuo mažmeninès prekybos tipo. Venskus (1993) teigia, kad pagal parduotuvių tipus mažmeninès prekybos asortimentas gali būti: universalus, kompleksinis, specializuotas. Taip pat galima išskirti pagrindini ir šalutini parduotuvės asortimentą (Pajuodis, 2005).

Pateiktos prekių klasifikacijos, nors ir leidžia tam tikrais aspektais apibūdinti prekybos imonès asortimentą, tačiau yra nepakankamai konkrečios, kad jomis remiantis galima būtų valdyti asortimentą, ji 
analizuoti, planuoti, bei kontroliuoti. Asortimento valdymas reikalauja ji skirstyti taip, kad atsiradusias jo sudedamąsias dalis būtu galima kiekybiškai ir kokybiškai išreikšti, išmatuoti.

Kotler, Amstrong, Saunders, Wong (2003) siūlo vadovautis 7 prekių hierarchijos lygiais paremta asortimento klasifikacija:

- $\quad$ poreikiu šeima. Tai pagrindinis poreikis, sudarantis pagrindą prekių šeimos egzistavimui.

- prekiu šeima. Visos prekių klasès, kurios pakankamai efektyviai gali tenkinti pagrindini poreiki.

- prekiu klasė. Grupé šeimos prekių, turinti funkcinius tarpusavio ryšius.

- prekiu linija. Grupé analogiškomis funkcijomis glaudžiai susijusių prekių, siūloma toms pačioms pirkèjų grupèms, paskirstoma tais pačiais kanalais arba esanti vienodo kainų diapazono.

- prekés tipas. Grupe prekių linijos prekių atstovaujanti vienai iš galimų prekių formų (rūšiu).

- prekés ženklas. Pavadinimas, kuris asocijuojasi su viena ar keliomis prekemis iš tam tikros prekiu linijos ir naudojamas prekès šaltiniui ar pobūdžiui pažymèti.

- prekès vienetas. Tam tikro dydžio, kainos, išvaizdos ar kokia nors kita kokybès savybe pasižymintis prekès ženklo arba prekès asortimento gaminys.

Pajuodis (2005) pateikia Seyffert (1951) ir Berekoven (1990) siūlymais paremtą prekiu asortimento klasifikaciją (asortimento piramidę): prekiu rūšis / pozicija, prekès pavadinimas, prekiu pavadinimu grupé, prekiu grupè, prekiu šeima, prekiu šaka ir visas prekiu asortimentas.

Pagal tam tikrą požymị sujungus ìvairių pavadinimų prekes, gaunamos prekiu grupès, kurias dar galima jungti $i$ aukštesnio lygio klasifikavimo vienetus.

Asortimento turinio, jo sudèties nustatymas yra svarbus asortimento politikos sprendimu prièmimo etapas. Reikia nepamiršti, kad prièmus sprendimus tam tikrame asortimento lygmenyje, apribojami sprendimų erdvės žemesni lygmenys. Kadangi visoms įmonėms asortimento lygmenu negalima nustatyti remiantis vienodais kriterijais, daugiamate asortimento piramidè praktikoje paprastai apribojama dvimate sistema, nustatančia asortimento plotį ir gyli.

Apibendrinant galima teigti, kad yra daug asortimento klasifikacijos kriterijų, kuriuos būtina ịvertinti siekiant asortimento optimizavimo. Kiekviena prekybos imonė savo asortimentui valdyti turètu parengti individualią prekių klasifikavimo sistemą, kuri atspindètų jos veiklos specifiką ir parduodamu prekiu asortimentą. Tačiau sudarant tokią sistemą kiekvienam asortimento lygmeniui būtina nustatyti aiškius, konkrečius požymius, kad tam tikrą prekę vienprasmiškai galima būtu priskirti vienam ar kitam lygmeniui.

\section{Asortimento parametrai ir struktūra}

Asortimento struktūros, dar kitaip vadinamos turiniu, sudètimi (Assel, 1974), nustatymas yra svarbus asortimento politikos sprendimų prièmimo etapas. Analizuojant asortimento struktūrą, būtina grižti prie asortimento klasifikavimo kriterijų ir dar kartą paminèti asortimento klasifikavimą pagal lygius. Būtent, remiantis šia klasifikacija, formuojama asortimento struktūra.

Baziniu (centriniu) asortimento vienetu reikètu laikyti prekès pavadinima. Prekès pavadinimas yra toks asortimento vienetas, kuris apibūdina prekę, galinčią patenkinti tam tikrą konkretu poreikị. Tačiau tą pati poreiki tenkinančios prekès gali skirtis ịvairiais antraeiliais požymiais, pavyzdžiui., modeliu, spalva, sudètimi, kilme, fasavimu ir pan. Tai yra skirtingi to paties pavadinimo prekių pavidalai.

Priklausomai nuo grupių ir pavidalų skaičiaus nustatoma asortimento piramidè, kuri dažniausiai praktikoje analizuojama dvimate sistema, nustatant asortimento gyli bei ploti.

1 lentelè. Asortimento parametrai

\begin{tabular}{|l|l|}
\hline \multicolumn{1}{|c|}{ Parametras } & \multicolumn{1}{c|}{ Apibūdinimas } \\
\hline Asortimento plotis & nusako, kiek yra iš esmès skirtingų prekių \\
\hline Asortimento gylis & Nusako, kiek kiekviena prekė turi modifikacijų, pavidalų, dydžių ir kt. \\
\hline
\end{tabular}

Asortimento pločiu suprantama ịvairios paskirties prekių pasiūla, sudaranti galimybes vieno apsilankymo prekybos (pirkimo) vietoje metu patenkinti ivairius poreikius (Levy, Weitz, 2008). Apie asortimento plotị sprendžiama iš skirtingos paskirties prekių skaičiaus. Jị galima nustatyti remiantis prekių grupių skaičiumi. Asortimento gylis pirkejjui sudaro alternatyvias tam tikros paskirties prekiu pasirinkimo galimybes. (Levy, Weitz, 2008) I t asortimento gyli reikia žiūrèti vertikaliu pjūviu. Jị sudaro daugybė skirtingų pavadinimų prekių, jų rūšys. 
$\mathrm{Su}$ šiomis asortimento charakteristikomis susijęs asortimento formavimo pobūdis ir pagrindinis tikslas - kiek prekiu grupiu ir pavidalu turèti. Pagrindinis kriterijus - tai vartotojo poreikiu patenkinimas. Todèl formuojant asortimenta, labai svarbu ir reikšminga yra orientuotis i bendrą imonès marketingo strategija, ištirti konkurencinę aplinką, pačios įmonès gamybinius pajègumus bei asortimento struktūrą.

Pagal asortimento platumą ir gilumą gali būti sudaromas kelių rūšių asortimentas, kur derinami skirtingi platumo ir gilumo parametrai. Asortimento pločio ir gylio matmenys ne tik išreiškia skirtingas pirkimo galimybes, bet ir, priklausomai nuo konkrečios paklausos situacijos, sukuria skirtingą asortimento patrauklumo efektą (Levy, Weitz, 2008). Asortimento plotis ir gylis dažnai yra suprantami nevienodai, kartais jie net neskiriami. Ypatingai tokių prekių, kurios turi sudètingą grupavimo požymių sistemą ir pakopiškumą, asortimento plotis ir gylis gali sutapti. Aukštesnès pakopos asortimento gylis pagal žemesni klasifikavimo lygi gali būti laikomas asortimento pločiu.

Pirkejjai visuomet nori, kad prekybos įmonèje būtų kiek galima didesnis prekiu pasirinkimas, kad jos būtu geros kokybès, kad būtu patogu jas apžiūrèti prekybos salèje. Asortimentas yra optimalus tik tuomet, kai prekybos imoniu pasiūla atitinka jos paklausą. Tačiau nėra pageidautinas nei asortimento perviršis, dèl kurio prekès užsiguli, nei asortimento trūkumas, dèl kurio nepasinaudojama galimybe realizuoti prekes.

Mokslininkai teigia, kad asortimentas yra per siauras, jei pelnas padidètų papildžius ji naujomis prekèmis, o per platus - kai pelnas padidètų atsisakant kai kurių prekių.

Be gylio ir pločio asortimentą apibūdina ir jo kaita. Tai yra svarbus rodiklis, charakterizuojantis prekiu pasirinkimą ir asortimento savybes.

Apibendrinant asortimento struktūros analizę, reikètu pastebėti, kad teoriškai neįmanoma nustatyti, koks asortimento plotis ir gylis yra optimalus. Tai galima padaryti tik konkrečiu atveju, t.y. konkrečioje imonèje, ivvertinus, visu pirma, jos pirkejju poreikius, antra jos dydi, o vèliau ir visus kitus veiksnius. Tai reiškia, kad asortimento struktūros sprendimus lemia ne kas kita kaip veiksnių, sąlygojančiu asortimento formavima, struktūros įvertinimas bei asortimento klasifikacijos sistema.

\section{Asortimento formavimo metodai}

Fisher, McClelland (2000) teigia, kad asortimento formavimui vien tik vadovo intuicijos neužtenka. Šie autoriai pažymi, kad asortimento formavimas turètu būti pagrịstas ir analitiniais metodais. Akademinëje literatūroje autoriai (Aydin, Hausman, 2002; Chong, Ho, Tang, 2001; Kök, Fisher, 2004; Mahajan, van Ryzin, 1999 ir kt.) pateikia daugybę asortimento planavimo ir formavimo metodu.

Borle, Boatwright, Kadane, Nunes, Shmueli (2005) asortimento formavime siūlo taikyti pirkimo dažnio - kiekio metodus, kuriuos klasifikuoja i tiekimo intervalu, prekiu kategoriju ir pirkimo elgsenos metodus.

Kök, Fisher, Vaidyanathan (2006) išskiria asortimento lygmenu formavimo, vietos lentynose ¿vertinimo, atsargu valdymo, daugianario asortimento sudarymo, paklausos ivertinimo, lokaliu veiksniu ivertinimo ir vartotoju elgsena gristi metodus.

Fisher, Vaidyanathan (2009) dar itraukia ir prekiu pelningumu gristus modelius bei asortimento optimizavimo modelius.

Galima pastebèti, kad asortimento formavimo metodu pasirinkimas, kaip teigia dauguma autoriu, labai priklauso nuo situacijos mažmeninės prekybos i̇monèje, nuo jos politikos; taip pat, kad dauguma metodų susiję su paklausos, pirkejju poreikių vertinimu, mažmeninès prekybos įmonės politika.

Su pirkimo elgsena siejamus metodus galima suskirstyti i dvi grupes: parduotuvės lygmens bei prekių kategorijų lygmens metodus. Pirmoji metodų grupė yra skirta sekti asortimento realizavimo pokyčius, susijusius su pirkejų sprendimais, itraukiant pirkimo laiko ir pirkimo kiekio veiksnius. Kategorijos lygmens metodai apima analitinius metodus, kuriais stebimi tam tikros prekių kategorijos pokyčiai, taip pat laiko bei kiekio aspektai. Parduotuvès lygyje modeliuojamas bendras laiko bei kiekio pasiskirstymas visam asortimentui ir įtaka asortimento mažejjimui parduotuvèse. Šie du veiksniai - laikas ir kiekis - vertinami kaip bendri kintamieji. Tuo tarpu prekių kategorijų lygmenyje asortimento pokyčiams įvertinti dažnai naudojami nepriklausomi metodai (aplinkos sąlygos parduotuveje) ir bendri metodai, vertinantys visas prekiu kategorijas ir jų įsigijimo procedūrą parduotuvèje.

Borle, Boatwright, Kadane, Nunes, Shmueli (2005) išskirti metodai taikomi ne naujo asortimento formavimui, tačiau jau suformuoto asortimento sekimui bei koregavimui. Huiskonen (2001) pažymi, kad asortimento stebejjimo (sekimo) tikslas yra stebèti asortimento judèjimą ir atlikti naujus užsakymus, kai asortimento atitinkamų kategorijų likutis pasiekia numatytą lygi. 
Galima teigti, kad šie parduotuvès lygio metodai leidžia įvertinti visos mažmeninès prekybos i̇monès asortimentą per atskirų produktų kategorijų prizmę ir daryti išvadas dėl viso asortimento sprendimų. Šie metodai paprastai taikomi tik atlikus asortimento analizę.

\section{Konceptualus asortimento formavimo mažmeninėje prekyboje modelis}

Nėra pakankamai žinių, kaip ir kuo remiantis mažmeninès prekybos įmonės - tiek didieji prekybos tinklai, tiek ir mažos, nepriklausomos parduotuvès - formuoja savo prekių asortimentą. Pagrindiniai tyrimai daugiau apėmè sprendimų dẻl asortimento dydžio pagrindimą, o apie asortimento struktūrą tyrimų nèra daug (Bayus, Putsis, 1999; Kadiyali, Vilcassim, Chintagunta, 1999; Draganska, Jain, 2005; Richards, Hamilton 2006; Misra, 2008). Galima aptikti gana prieštaringų siūlymų apie tai, kaip turètų būti formuojamas asortimentas, t.y. koks turètų būti formavimo procesas. Dauguma mažmeninès prekybos i̇monių asortimenta formuoja, priklausomai nuo asortimentui priskiriamu tikslų, pajëgumu ji parduoti ir, žinoma, pirkejų poreikių. Asortimento formavimas yra procesas, turintis tam tikrus etapus, kuriuos reikia igyvendinti, siekiant suformuoti efektyvų asortimentą. Be to, tai nepertraukiamai vykstantis procesas visų pirma todèl, kad nuolat kinta prekių pasiūla (kiekybiniu, struktūros bei kokybiniu atžvilgiais), o antra, kad visas prekiu cirkuliacijos procesas vyksta taip pat nepertraukiamai.

Dune, Lusch (2005) teigimu, asortimento formavimo procesas susideda iš pagrindinių veiksmu analizès, planavimo, kontrolès. Tai pasireiškia visomis formomis - realizuojant, gaunant prekes bei kaupiant jų atsargas. Galima išskirti keturis pagrindinius asortimento formavimo etapus.

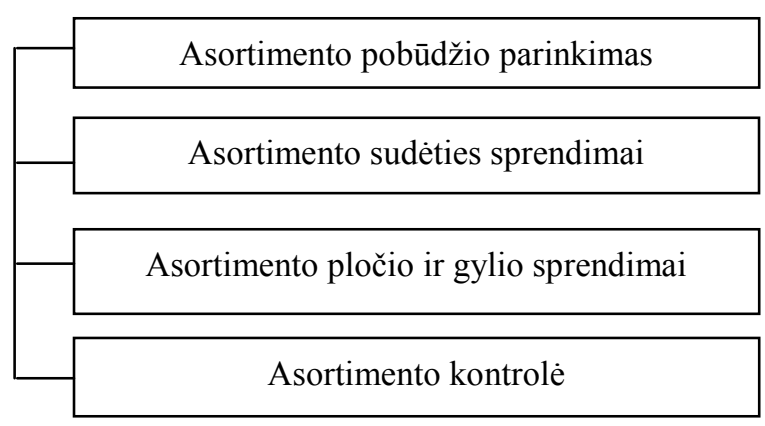

1 pav. Prekybos įmonès asortimento formavimo etapai (pagal Dune, Lusch, 2005)

Kaip matyti iš paveikslo, prekybos i̇monès asortimento formavimas susideda iš: 1. Asortimento pobūdžio nustatymo (apsprendžia, kokiomis prekėmis prekiaus i̇monè); 2. Asortimento sudèties nustatymo (sprendžiami prekių užsakymo, realizavimo ir atsargu apimties klausimai); 3. Asortimento pločio ir gylio nustatymo bei 4. Prekių asortimento kontrolès. Kontrolès etapas reiškia, jog visi etapai pradedami iš naujo, nes asortimento formavimas - tai nuolat atnaujinantis asortimentą procesas. Prekybos profilio pasirinkimas yra vienintelis iš šių etapų, kuris vykdomas vieną kartą - steigiant prekybos įmonę, tačiau ir tai gali būti laikas nuo laiko peržiūrima, jei pasirodo, jog vartotojų poreikiai radikaliai pasikeitė.

Ross (1995) siūlo asortimento formavimo modeli jau veikiančioje imonèje, t.y. šis autorius, pateikdamas asortimento planavimo procesa, daugiau orientuojasi i jo optimizavimo aspektus.

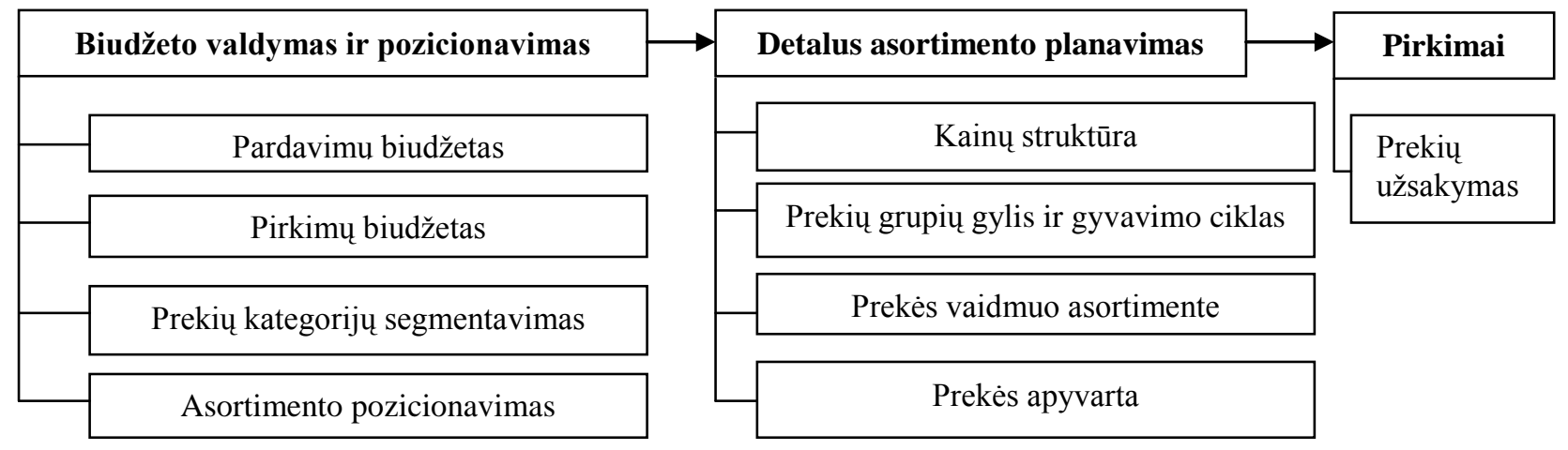

2 pav. Asortimento formavimo procesas (pagal Ross, 1995) 
Jeigu aukščiau pateiktame paveiksle, asortimento planavimo procesas prasidètu antruoju etapu, jis galètų būti taikomas ir naujos mažmeninès prekybos įmonès asortimento formavimui.

Wilkie (1994) pateikia išsamesni, labiau detalizuotą asortimento formavimo procesą. Modelis pradedamas informacijos rinkimo etapu, kuris apima kiekybini ir kokybini gautos informacijos įvertinima, prekiu pasirinkimo prognozavimą bei trumpojo laikotarpio pardavimų prognozes. Pagal prognozių duomenis planuojama, kokiomis prekių grupėmis, prekių ženklais prekiauti, kokias prekių modifikacijas, spalvas bei dydžius, pakuotes pasirinkti. Pagal pardavimo apimčių prognozes Wilkie (1994) siūlo formuoti atskiru prekių grupių, prekių ženklų užsakymus, įvertinant prekių spalvas, dydžius, pakuotes ir pan.

Remiantis anksčiau aptartais modeliais, ir asortimento formavimo metodais, 3 paveiksle pateikiamas konceptualus mažmeninès prekybos asortimento formavimo modelis.

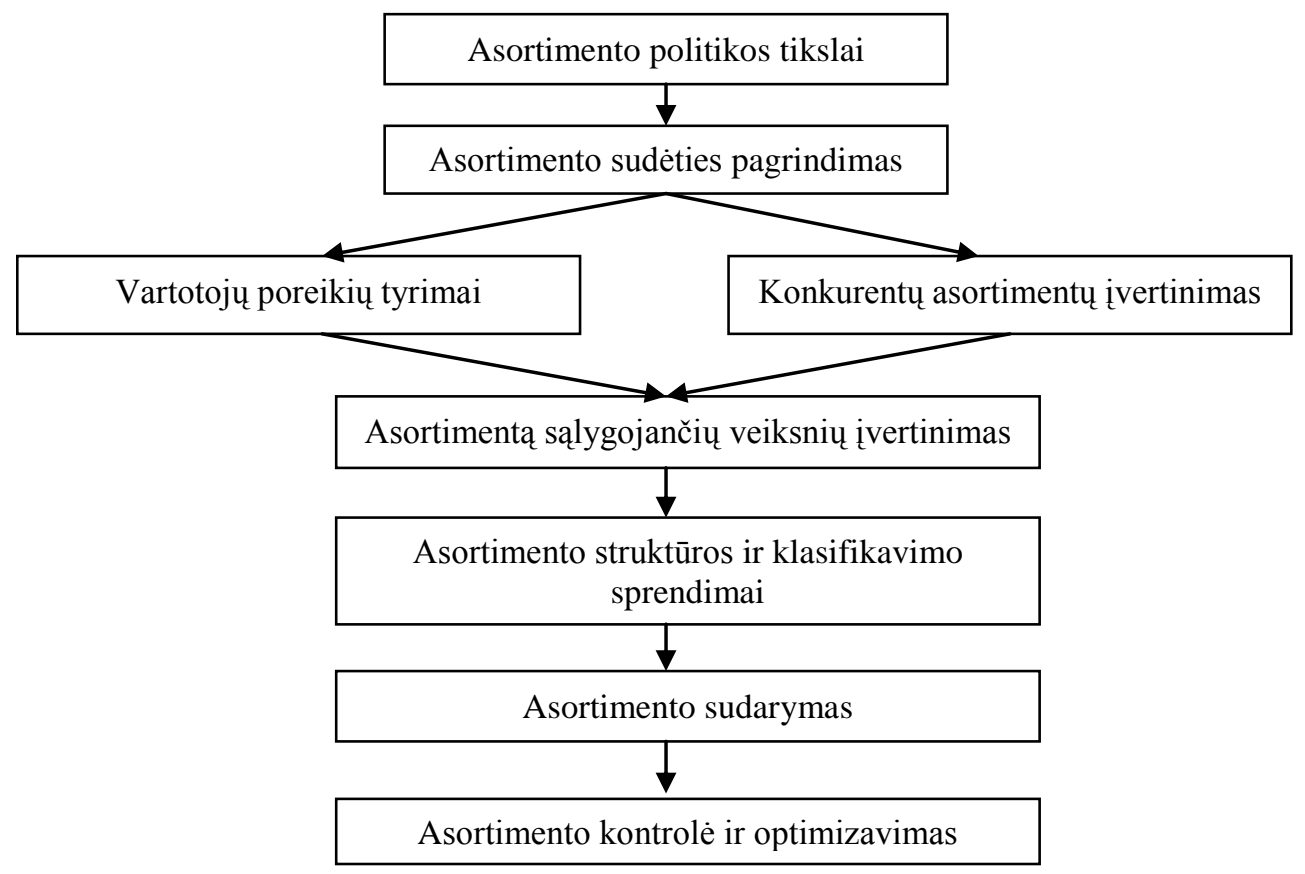

3 pav. Konceptualus mažmeninės prekybos asortimento formavimo modelis

Šis modelis sudarytas remiantis Dune, Lusch (2005), Sullivan, Adcock (2002), Kök, Fisher (2004), Mahajan, van Ryzin (1999) ir kt. siūlymais, nors šie autoriai savo darbuose konkretaus proceso nepateikia.

Kaip matyti iš paveikslo, asortimento formavimas apima ir optimizavimą. Šis modelis gali būti taikomas ir asortimento formavimui taikant atitinkamą programinę irangą. Tokiu atveju tai būtų daugiau asortimento efektyvumo analizè, kuri padètu priimti programos sugeneruotus sprendimus dèl atitinkamu prekių grupių išlaikymo asortimento struktūroje ar jų pašalinimo.

Taigi, kaip matyti iš konceptualaus asortimento formavimo modelio, kaip ir bet koks planavimo ar kūrimo procesas, visų pirma, asortimento formavimas prasideda nuo jam iškeliamų tikslų. Asortimento politikos tikslai turi išplaukti iš bendru i̇monès tikslų. Dažniausiai keliami konkrečių pajamų iš prekybinio antkainio tikslai (Pajuodis, 2005), kurie tiesiogiai siejasi su pelningumu ir apyvartos didinimu.

Asortimento formavimo procesas apima antrinių bei pirminių duomenų rinkimą ir analizę. Formuojant asortimenta, pirmiausia būtina atlikti prekybos imonès tikslinio segmento ir konkurentų tyrimus, kurie padėtų nustatyti pirkèjų poreikius bei įvertinti artimiausių konkurentų veiksmus. Simonson (1999) siūlo konkurentų asortimento tyrimo rezultatus apjungti su pirkejjų poreikių tyrimo metu gautais rezultatais ir jais remiantis priimti bendrą sprendimą, kuris būtų prekybos įmonès asortimento formavimo pagrindas.

Prekybos imonė taip pat privalo i̇vertinti veiksnius, darančius itaką asortimento formavimui, asortimento klasifikavimo kriterijus ir sudaryti savo prekių klasifikacija, priimti su asortimento struktūra susijusius sprendimus. Šių etapu igyvendinimui galima pasitelkti straipsnyje aptartus asortimento formavimo metodus.

Asortimento formavimas mažmeninès prekybos imonèje yra nenutrūkstamas procesas, nes vartotojų paklausa nuolat kinta, nèra statiška. Todèl norint prekybos asortimentą padaryti efektyvu, ji reikia pastoviai kontroliuoti. Asortimento efektyvumo analizė sudaro prielaidas esamo asortimento optimizavimui. 


\section{Išvados} išvadas:

Apibendrinant straipsnyje pateiktu teorinius asortimento formavimo aspektus, galima daryti tokias

1. Mokslinès literatūros, analizè leidžia daryti išvadą, kad asortimento formavimas mažmeninès prekybos i̇moneje yra vienas sudetingiausių šios veiklos etapų. Asortimentas yra vienas iš kriterijų, išskiriančių mažmeninès prekybos i̇mones pagal tipus. Nuo asortimento labai priklauso prekybos i̇monès sèkmè. Todèl, formuojant asortimentą būtina turèti numačius procesą, kuriuo visa ši veikla bus vykdoma.

2. Žinant, kad asortimentas yra vienas iš kriterijų, pritraukiančių daugiau pirkejjų, asortimentui skirtas ypatingas dėmesys užsienio mokslininkǔ darbuose. Mokslinès literatūros analizė leido daryti išvadą, kad asortimento formavimui užsienio mokslininkai skiria pakankamai dideli dèmesi: asortimento formavimas bei efektyvumas analizuojamas tiek teoriniame, tiek ir empiriniame lygmenyje, išskiriant ịvairius metodus, kuriais tiriamas prekiu grupių efektyvumas, paklausa. Lietuvos mokslininkai apie asortimento formavimą plačiau diskutuoja akademinejje teoriniame lygmenyje, todèl empirinių tyrimų stoka neleidžia ịvairiapusiškai pagrịsti mažmeninių prekybos įmonių asortimento formavimo principu.

3. Kiekviena mažmeninès prekybos i̇monè pati modeliuoja asortimento formavimo procesą, priklausomai nuo jos poreikių bei lūkesčių. Tačiau praktika rodo, kad dažnai imonès to nedaro, asortimentas formuojamas vadovaujantis intuicija arba netiksliais metodais, neivertinant veiksniu ir galimos rizikos, kas sąlygoja asortimento formavimo klaidas ir sąlygoja apyvartos sumažèjimą, rinkos dalies praradimą ir pan.

4. Atlikta mokslinès literatūros analizė leidžia daryti išvadą, kad asortimento formavimas yra ilgas procesas, kuris turi būti igyvendinamas laipsniškai, tiksliai, detaliai. Apibendrinus asortimento klasifikavimo kriterijus, asortimento struktūrą ir formavimo metodus, pateikiamas konceptualus mažmeninès prekybos asortimento formavimo modelis. Kiekvienas modelio elementas glaudžiai susijęs su kitais elementais. Sudarytame modelyje išskiriami tokie elementai kaip asortimentui itaką darantys veiksniai, klasifikavimo kriterijai, struktūra, asortimento kontrolè ir optimizavimas.

\section{Literatūra}

1. Kotler, P., Amstrong, G., Saunders, J., Wong, V. (2003). Rinkodaros principai. Kaunas: Poligrafija ir informatika.

2. Pajuodis, A. (2005). Prekybos Marketingas. Vilnius: Eugrimas.

3. Pranulis, V., Pajuodis, A., Urbonavičius, S.,Virvilaitè, R. (2011) Marketingas [Vadovėlis], 4-as patais. ir papild. leid. Vilnius: Garnelis.

4. Sūdžius, V. (1997). Imonių komercija: principai ir praktika. Vilnius: Pačiolis.

5. Aydin, G., Hausman, W.H. (2002). Supply chain coordination and assortment planning. Stanford, CA: Stanford University.

6. Assel, H. (1974). Product classification and the theory of consumer behavior. Journal of the Academy of Marketing Science, 2 (4), 539-552.

7. Bayus, B.L., Putsis, W.P. (1999). Product Proliferation: An Empirical Analysis of Product Line Determinants and market Outcomes. Marketing Science, 18 (2), 137-153.

8. Borle, SH., Boatwright, P., Kadane, J.B., Nunes, J.C., Shmueli, G. (2005). The effect of product assortment changes on customer retention. Marketing science, 24 (4), 616-622.

9. Chernev, A. (2006). Differentiation and Parity in assortment pricing. Journal of consumer research, 33, $199-211$.

10. Chong, J.K., Ho, H., Tang, S. (2001). A modeling framework for category assortment planning. Manufacturing service operation management, 3(3), 191-210.

11. Draganska, M., Jain, D.C. (2005). Product-Line Length as a Competitive Tool. Journal of Economics and Management Strategy, 14 (1), 1-28.

12. Dune P.M., Lusch R.F. (2005). Retailing. USA: Thomson, South-Western.

13. Fisher, M.R., Mcclelland, R.A. (2000). Rocket science retailing is almost here - Are you ready? Harvard Business Review, 78 (4), 115-124.

14. Fisher, M.L., Vaidyanathan, R. (2009). An Algorithm and Demand Estimation Procedure for Retail Assortment Optimization. Philadelphia: The Wharton School. 
15. Fox, E.J., Sethuraman, R. (2006). Retail Competition in Retailing in the 21st Century: Current and Emerging Trends. New York: Springer.

16. Gaur, V., Honhon, D. (2006). Assortment planning and inventory decisions under a locational choice model. Management Science, 1528-1543.

17. Gürhan, A. K, Marshall, L. F, Ramnath, V. (2006). Assortment Planning: Review of Literature and Industry Practice. Retail Supply Chain Management, Eds. N. Agrawal and S. A. Smith, Kluwer Publishers.

18. Grewal, D., Levy, M., Mehrotra, A., Sharma, A. (1999). Planning Merchandising Decisions to Account for Regional and Product Assortment Differences. Journal of Retailing, 75 (3), 405-424.

19. Hyman, M.R., Sharma, V.M., Krishnamurthy, P. (1994). A Provider-Cost Patron-Effort Schema for Classifying Products. Journal of the Academy of Marketing Science, 23 (1), 15-25.

20. Hsu, A., Bassok, Y. (1999). Random yield and random demand in a production system with downward substitution. Operations Research, 47 (2), 277-290.

21. Huiskonen, J. (2001). Maintenance spare parts logistics: Special characteristics and strategic choises. International Journal of Production Economics, 71, 125-133.

22. KadiyalI, V., Vilcassim, N., Chintagunta, P. (1999). Product Line Extensions and Competitive Market Interactions: An Empirical Analysis. Journal of Econometrics, 89 (1-2), 339-363.

23. Kök, A.G., Fisher, M.L. (2004). Demand estimation and assortment optimization under substitution: Methodology and application. Durham: Fuqua School of Business, Duke University.

24. Kök, A.G., Fisher, M.L., Vaidyanathan, R. (2006). Assortment planning: Review of literature and industry practice. Retail Supply Chain Management, Eds. N. Agrawal, S.A. Smith. Kluwer Publishers.

25. Kök, A.G., Fisher, M.L. (2007). Demand Estimation and Assortment Optimization Under SubstitutionMethodology and Application. Operations Research, 2007, 55 (6), 1001-1021.

26. Kotler, Ph, Keller, K. L.(2007). Marketingo valdymo pagrindai. Klaipèda, Logitema.

27. Lewy M., Weitz B. (2008). Retailing Management, 7-ed. - McGraw-Hill, Irwin.

28. Linehan, M., Cadogan, T. (2003). Marketing. Second Edition. Ireland: Gill\&Macmillan Ltd.

29. Mahajan, S., van Ryzin, G. (1999). Quantitative models for supply chain management. Retail inventories and consumer choice, Kluwer Academic Publishers, 491-551.

30. Mantrala, M.K., Levy, M., Kahn, B.E., Fox, E.J., Gaidarev, P., Dankworth, B., Shah, D. (2009). Why is Assortment Planning so Difficult for Retailers? A Framework and Research Agenda. Journal of Retailing, 85 (1), 71-83

31. Misra, K. (2008). Understanding Retail Assortments in Competitive Markets. Northwestern University.

32. Noonan, P. (1995). When consumers choose: a multi-product, multi-location newsboy model with substitution. Technical report, Emory University, Atlanta, Georgia.

33. Parlar, M., Goyal, S. K.. (1984). Optimal ordering decisions for two substitutable products with stochastic demands. Opsearch, 21, 1-15.

34. Rajaram, K., Tang, C. S. (2001). The impact of product substitution on retail merchandising. European Journal of Operational Research, 135 (3), 582-601.

35. Richards, T.J., Hamilton, S.F. (2006). Rivalry in Price and Variety among Supermarket Retailers. American Journal of Agricultural Economics, 2006, 88 (3), 710-726

36. Ross, L. (1995). Retail planning policies in Western Europe. London: Routledge.

37. Simonson, I. (1999). The effect of product assortment on buyer preferences. Journal of Retailing, 75 (3), $347-370$.

38. Skalen, P., Fougere, M., Felleson, M. (2008). Marketing Discourse. A Critical Perspective. New York: Routledge.

39. Sullivan, M. \& Adcock, D (2002). Retail Marketing; London: Thomson.

40. Wilkie, W.L. (1994). Consumer behavior (3rd Ed.). New York: John Wiley \& Sons, INC. 